\title{
Innovations and Export Performance: Firm-level Evidence from Poland
}

\author{
Andrzej Cieślik, Jan Jakub Michałek, Krzysztof Szczygielski
}

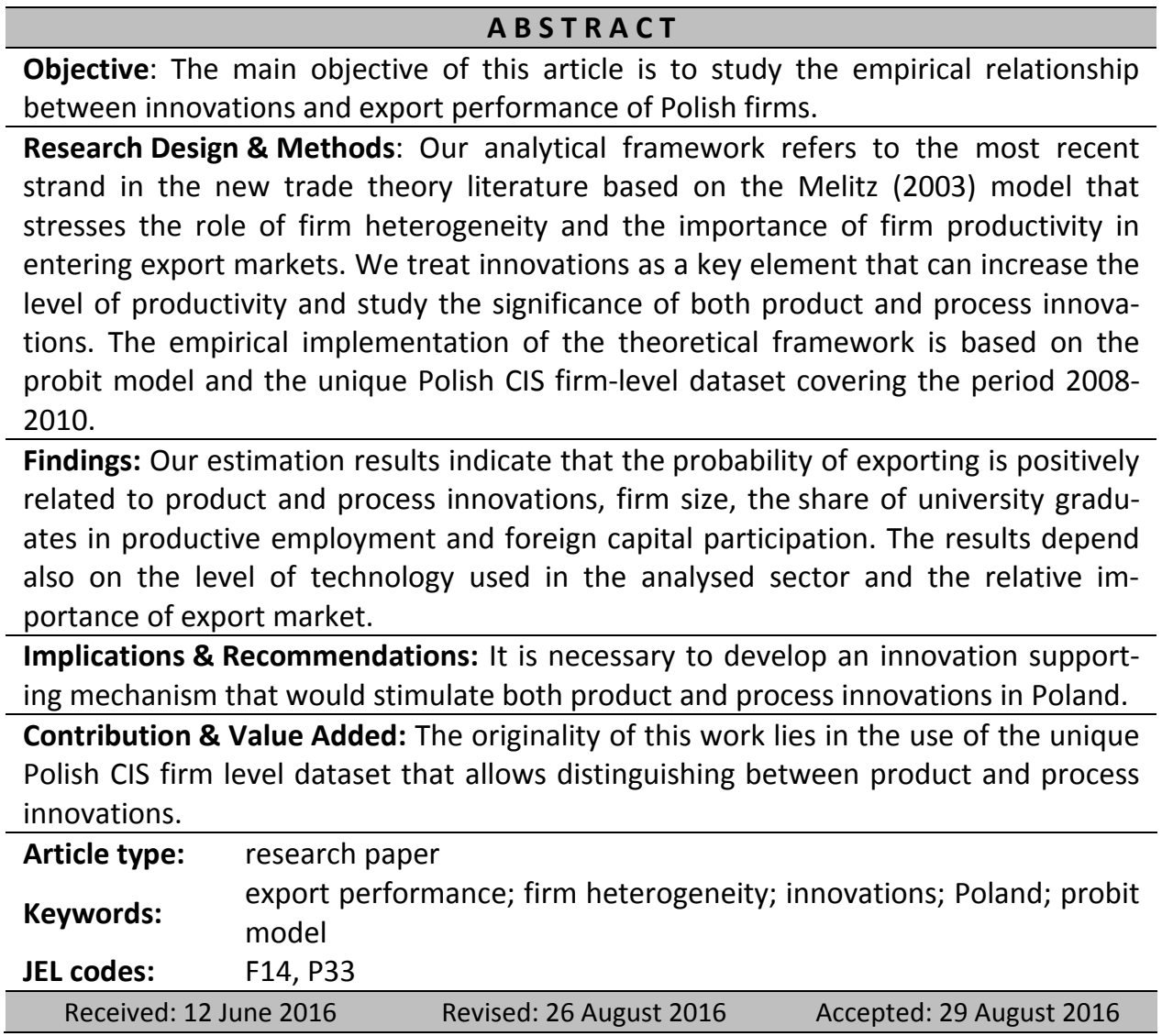

\section{Suggested citation:}

Cieślik, A., Michałek, J.J., \& Szczygielski, K. (2016). Innovations and Export Performance: Firm-level Evidence from Poland. (2016). Entrepreneurial Business and Economics Review, 4(4), 11-28, DOI: http://dx.doi.org/10.15678/EBER.2016.040402 


\section{INTRODUCTION}

Innovation is one of the key terms related to the modernization and development of the EU economy. However, empirical studies devoted to the subject in the context of international competitiveness at firm level are relatively few. Innovation activities cover product and process innovations as well as the creation of intellectual property rights related to patents and trademarks. Previous studies have focused almost exclusively on the analysis of companies in developed countries such as Germany or the United Kingdom, with a high levels of firm innovation. These studies have mainly focused on product and process innovation.

One of the key elements of innovation activity, analysed in the context of firm export performance in the old EU-15 member states, is research and development (R\&D) activity. This activity is described as the process of systematic creative work that combines both basic and applied research aimed at extending the company's knowledge resources and its practical application. Measures of innovative activity of companies can include spending on R\&D as well as its effects, such as patents and share of new products in total sales. $R \& D$ may result in improved efficiency of the company.

The main objective of this paper is to study the relationship between innovation of Polish firms and their export competitiveness. In particular, we empirically validate the main hypothesis concerning the positive relationship between innovation activities and exports performance using the probit model. In contrast to previous studies that use $R \& D$ spending as a measure of innovation, we focus on innovation outcomes. Our detailed hypotheses postulate the existence of positive relationships between firm export performance and different types of innovation activities: product and process innovations. We seek to determine which of the aforementioned types of innovation activity is of the greatest importance for exporting and whether it depends on firm size, the level of internationalization, the use of human capital and its sector of activity. In addition, we take into account the intellectual property creation at firm-level. Our study is based on Polish firm-level data for the period 2008-2010.

The results of our study can contribute to proposing a set of policy conclusions that can apply to Poland and other New Member States (NMS) of the European Union. The firms from those countries are lagging behind in terms of innovation activities and their presence in foreign markets is still limited compared to the firms from the old EU-15. This is particularly important in the light of changes in the allocation of the EU funds in the current Financial Perspective, i.e. increasing expenditure for innovative firms, aimed at increasing their presence in the global markets. This study should also contribute to a better understanding of the mechanisms of cooperation between managers, engineers, scientists and research centres serving to create new processes, products and technological progress as well as social development of the NMS.

The structure of this paper is as follows. In the next section we provide the literature review. Then, we describe the dataset and the analytical framework. Subsequently, we present and discuss our empirical results. The last section summarizes and concludes. 


\section{LITERATURE REVIEW}

There is an extensive theoretical literature on the determinants of innovation and their consequences for productivity and exporting. In particular, a key hypothesis in this literature is that innovation is a driver of productivity improvement that in turn could stimulate exports. This literature has identified two main types of innovation: product innovation and process innovation. Product innovation is a key factor for successful market entry in models of creative destruction and Schumpeterian growth while process innovation reduces costs of production and improves firm's market position. Both modes of innovation are expected to raise firm's productivity and propensity to export.

The early endogenous growth theory literature traditionally stressed the importance of product innovation in for economic growth in a world where consumers have a desire for variety and/or a high quality of available products (Grossman \& Helpman, 1991). ${ }^{1}$ Later, economists started to explore the potential differences between product and process innovation focusing on heterogeneous agents and technological unemployment (Foellmi \& Zweimüller, 2006). In dynamic models with heterogeneous firms (Jovanovic, 1982; Hopenhayn, 1992; Melitz, 2003; Grossman, Helpman \& Szeidl, 2006), investment in firm-specific assets that could be associated with product innovation led to a selection of firms. The least productive ones did not participate in the market at all and the most productive ones supplied consumers not only at home but also abroad (through exports), while those with an intermediate productivity only faced demand from domestic consumers. In this context, investment in firm-specific assets and a high total factor productivity were considered as the key determinants of a firm's export propensity. ${ }^{2}$

Most recently, Atkeson and Burstein (2007) and Constantini and Melitz (2008) have analysed dynamic industry models to formalize the relationships between firm-level productivity and the choices of both to export and to invest in R\&D or adopt new technology. In these models, productivity distinguishes heterogeneous firms, and its evolution is endogenous and affected by innovation decisions at the firm level apart from a stochastic component.

There is also extensive empirical literature that points to a positive impact of innovation as such on exports at the firm- or plant-level. The majority of the existing studies rely on R\&D expenditures as an indirect measure of innovations (Hirsch \& Bijaoui, 1985; Kumar \& Siddharthan, 1994; Braunerhjelm, 1996; Basile, 2001). Early empirical studies (Hirsch \& Bijaoui, 1985; Schlegelmilch \& Crook, 1988) that looked into the effects of innovations on exports used measures of innovation input and arrived at mixed conclusions (Ebling \& Janz, 1999).

\footnotetext{
${ }^{1}$ However, the literature on the relationship between innovation and international trade is much less numerous. International economics focuses on the role of product innovation for trade in open economy growth models (Dollar, 1986; Jensen \& Thursby, 1987; Grossman \& Helpman, 1989; 1990; 1991; Segerstrom, Anant \& Dinopoulos, 1990).

${ }^{2}$ At the same time the early industrial organization literature stressed the role of marginal cost-reducing innovations (i.e. expenditures for research and development for the sake of process innovation) in international oligopoly models (Spencer \& Brander, 1983). According to this literature a higher investment in such process innovations increases a firm's output sold in domestic and foreign markets. Subsequent research focused on the relationship between process innovation and competitive pressure at the local (Martin, 1993) and the global level (Baily \& Gersbach, 1995).
} 
In addition, there is a limited number of studies that employ survey data with explicit information on the actual innovations (Wakelin, 1998; Bernard \& Jensen, 1999; Roper \& Love, 2002; Lachenmaier \& Wößmann, 2006). In particular, firm-level studies which used more direct measures of innovation output (i.e., actual innovations) are those of Wagner (1996) and Wakelin (1997; 1998). Wagner (1996) used a sample of firms in the German State of Lower Saxony and found a positive impact of new products introduced on exports. Wakelin (1998) employed British data and reported a positive impact of innovating on the intensive and extensive margins of exports at the firm level. Overall, these studies find a strong positive impact of innovations on export performance.

There is also some evidence on a systematic determination of innovation. Probably, the first empirical study on the impact of endogenous innovations on exports is the one by Entorf, Krader and Pohlmeier (1988). They estimated a simultaneous equation system of exports, innovation, and labour demand and identify not only a positive impact of innovations (captured by an indicator variable) on exports but also one of exports on innovations based on data from the Ifo Innovation Survey. Ebling and Janz (1999) studied the impact of innovations (captured by a binary variable) on the extensive margin of exports in the service sector, using data for 1997 from the Mannheim Innovation Panel. Their results were based on a two-step probit model and simultaneous probit models and pointed to a positive impact of innovations on exports, but not vice versa.

Van Beveren and Vandenbussche (2010) analysed the relationship between firmlevel innovation activities and firms' propensity to start exporting for Belgian firms. They measured innovation by innovative effort (R\&D) as well as by innovative output (product and process innovation). Their evidence pointed to firms self-selecting into innovation in anticipation of their entry into export markets, rather than product and process innovation triggering entry into the export market. Their results suggested that governments could foster firm-level innovation through trade liberalization.

While Cassiman and Martinez-Ros (2007) found support for the product innovationproductivity-export link in data on Spanish firms, the reverse causal direction (exporting-process innovation- productivity growth) was investigated with a less success. Cassiman, Golovko and Martínez-Ros (2010) argued that the positive association found between firm productivity and exports in the literature relates to the firm's innovation decisions. Using a panel of Spanish manufacturing firms they find strong evidence that product innovation - and not process innovation - affects productivity and induces small non-exporting firms to enter the export market.

Caldera (2010) investigated the relationship between innovation and the export behaviour of Spanish firms over the period 1991-2002. He presented a simple theoretical model of the firm decision to export and innovate that guides the econometric analysis. Consistent with the predictions of the theoretical model, the econometric results suggested a positive effect of firm innovation on the probability of participation in export markets. The results further revealed the heterogeneous effects of different types of innovations on the firm export participation. In particular, product upgrading appears to have a larger effect on the firm export participation than the introduction of cost-saving innovations. These findings were robust to firm unobserved heterogeneity, dynamic specifications, and to the use of instrumental variables to control for the potential endogeneity between innovation and exporting. 
Lachenmaier and Wößmann (2006) used instrumental-variables procedures to estimate the impact of potentially endogenous innovations on exports based on the firm level data on 981 German firms for the year 2002. Their focus was on total innovations, but they also looked into product versus process innovations in one of their specifications. In broad terms, they found that impediments to innovations matter and that such variables could be used as identifying instruments for innovations. Their results showed that treating innovations as exogenous may lead to largely downward-biased estimates of the impact of innovations on firm-level exports.

Most recently, Becker and Egger (2013) also studied the effects of new product versus process innovations on export propensity at the firm level in Germany. They hypothesized that in line with the new trade theory product innovation should be relatively more important than process innovation. They investigated this hypothesis in a rich survey panel data set with information about new innovations of either type. With a set of indicators regarding innovation motives and impediments and continuous variables at the firm and industry level at hand, they determined the probability of launching new innovations and their impact on export propensity at the firm level through a double treatment approach to account for self-selection of firms into either type of innovation. Their results point to the importance of product innovation relative to process innovation for the decision to export. Firms that perform both process and product innovations have a higher probability to export than firms that do not innovate; however, when performed alone, product innovation is more important in the exporting behaviour of a firm than is process innovation. This can be viewed as evidence on the importance of the extensive margin in product space for a firm's entry into export markets. While process innovations increase a firm's probability to export only when being combined with product innovations, they marginally raise a firm's export-to-sales ratio at the intensive margin.

Hence, the majority of empirical studies for the old EU-15 countries find support for the positive relationship between various types of innovations and exporting. In particular, these studies find that firms that introduce either process or product innovations exhibit a higher probability to export than firms that do not innovate. However, product innovations seem to be more important in determining the export performance of firms than process innovations.

In the context of the new EU member states empirical evidence on the relationship between innovation and exporting is scarce. The only exception, to the best of our knowledge, is the study by Damijan, Kostevc and Polanec (2010) who explored the causal links between innovation and export activities of firms in Slovenia. First, from product innovation to productivity and to decision to export may effectively explain how a firm's decision to invest in R\&D and to innovate a product drives its productivity and triggers the decision to start exporting. Second, in the opposite direction, the link going from exporting to process innovation to productivity growth may be crucial to understand how export activity can force a firm to engage in process innovation, which in turn improves its productivity growth in the long run. Their empirical approach is to tackle both sides of this causality link using Slovenian microdata, including financial data, innovation survey data, industrial survey data, as well as information on trade flows, for the period 1996-2002. Their dataset allows them to test the prediction that a firm's innovation 
enhances its probability of becoming an exporter, and the prediction that learning effects of exporting will translate to a greater effort to innovate and thus to improvements in productivity.

They found no evidence that either product or process innovations increases the likelihood that a firm becomes a first-time exporter. However, they found evidence that past exporting status increases the probability that medium and large firms will become process innovators. At the same time they found no impact of past exporting on product innovations. Thus, their results did not confirm the implications of the Constantini and Melitz (2008) model and the findings of Aw, Roberts and Xu (2009) that in the case of Slovenian firms the linkage from product innovation to productivity growth drives the self-selection of more productive firms into exporting. However, they found some evidence in favour of learning-by-exporting of Slovenian firms, which was already indicated by Damijan and Kostevc (2006), De Loecker (2007) and Hagemejer and Kolasa (2008). In particular, Damijan and Kostevc (2006) demonstrated that these learning-by-exporting effects occur through the mechanism of process innovation enhancing firm technical efficiency and not through introduction of new products. It is important to note, however, that the results of the study by Damjan et al. (2010) may not generalize to the whole group of the new EU member states as Slovenia is a small open economy with the highest level of development among the NMS.

The empirical evidence on the link between innovation and export performance for Poland is virtually non-existent. The previous studies such as Cieślik et al. (2012; 2013; 2014 ; 2015) stress the importance of R\&D expenditure for the probability of exporting. However, so far no attempt has been made to study the link between innovation outcomes and the probability of exporting for Poland. Therefore, in this article we investigate empirically whether various innovative activities contribute to increased efficiency of firms from Poland and whether they improve their ability to compete and stay at international markets. First, in contrast to previous studies conducted for selected EU-15 countries, our study is based on the unique firm-level dataset collected by the Polish Central Statistical Office (CSO). This allows us to analyse the relationship between innovative activities and exporting for both all the Polish as well as particular groups of the firms depending on the origin of their ownership. Second, in contrast to previous empirical studies we distinguish and examine the relative importance for exports of two main types of innovation: product and process innovations as well as patents and trademarks that reflect the investment in firm-specific assets. Moreover, we identify the relative importance of specific types of innovation activities for the international competitiveness of firms from Poland, which are much less innovative when compared to companies from the old EU-15 member states. Finally, we distinguish between all exporters and firms for which exporting constitutes an important fraction of their sales.

In addition, our study will allow formulating specific recommendations for economic policy in Poland and other NMS, especially for policies to encourage innovation in these countries which differ from the old EU member states in terms of the level of economic development. As regards possible conclusions for economic policy for the old EU-15 countries, the findings of the previous studies suggest that policy instruments should be targeted towards specific innovations rather than innovation input, if these countries want to improve their export competitiveness in world markets. In particular, some 
authors have argued that in the case of the old EU-15 countries subsidies and other programs aiming at product innovations should be on average more likely to cause entry into export markets than general expenditures on R\&D or legal environments which particularly favour process innovations.

\section{MATERIAL AND METHODS}

The new strand in the trade theory argues that the level of firm productivity is critical for exporting. In particular, the Melitz (2003) model points at the existence of a positive relationship between firm productivity and export performance. In his model productivity differences among firms are exogenously given and each firm has to pay fixed costs of entry into domestic and foreign markets. The majority of empirical studies find support for the theoretical prediction of the Melitz model, i.e. that more productive firms selfselect into foreign markets. The survey of early empirical evidence on the relationship between firm productivity and exporting was provided by Tybout (2003). The extensive summaries of more recent empirical evidence on this relationship in particular countries were offered by Wagner (2007, 2012). According to the first survey by Wagner (2007), a large number of studies using data from different countries, report results showing that exporters and importers are more productive that non-exporters and non-importers. In particular, he argued that future exporters tend to be more productive than future non-exporters in the years before they enter the export market. Moreover, the empirical results for post-entry differences in performance between exporters and non-exporters point to faster productivity growth for the former group in only some studies. This picture was largely confirmed in the recent survey by Wagner (2012), i.e. his review provides extensive evidence in favour of the self-selection hypothesis. Therefore, in our paper we refer to the self-selection hypothesis.

As the main objective of this article is to study the relationship between innovation of Polish firms and their export performance we use the unique Polish CIS firm-level dataset covering the period 2008-2010. The Community Innovation Survey (CIS) is the principal survey of the innovation activities of firms in the European Economic Area and the EU candidate and associate countries. The methodology of the survey is based on the Oslo Manual, first published in 1992 and then revised in 1996 and 2005. The CIS contains questions referring to revenue and expenditure in the most recent years (e.g. in 2010 in CIS 2008-2010), as well as questions about various aspects of innovation in the three years preceding each edition of the survey (e.g. in 2008-2010). Apart from innovationrelated information firms are required to answer questions about their revenue; the number of staff; whether they are members of groups of firms (where a group of firms is defined as a set of companies owned by the same person or entity), and if so then where is the mother company located; whether they have exporting activities and what is the main markets to which they sell.

However, the firm-level data from the CIS are not easily available for Poland. They are not available for researchers at the Eurostat's Safecentre in Luxembourg. It is possible to purchase raw data, but the information about revenues and expenditure is considered confidential, resulting in considerable restrictions with respect to the scope of data made available to researchers. 
This study is based on the Polish dataset for manufacturing companies patterned on CIS 2010 with some alterations. Due to the confidentiality conditions imposed by the Polish Central Statistical Office (CSO), data on revenue and the exact number of staff was unavailable; instead we only had information on the firm size category (i.e. small, medium, big). Data on innovation expenditure was available only on a per-capita basis. In comparison to the CIS survey in the Polish dataset there is additional information on the number of production lines both automatic and controlled by computers. All of the manufacturing firms employing more than 49 persons were surveyed, as well as a sample of firms employing 10-49 people. This resulted in 9,841 in the $2010 \mathrm{CIS}$.

In our study we refer to the classification of manufacturing industries proposed by the OECD (2012). According to this classification there are 4 categories based on R\&D intensities described in detail in the Annex. ${ }^{3}$

Our dependent variable, export performance, indicating the export status of the firm takes two main forms based on the Polish CSO questionnaire. The first form of the variable (exporter) takes value zero if the firm sells its output only in the domestic market, and one otherwise, i.e. if it sells also some of its output abroad. The second form of the variable (exporter_plus) takes value one if the foreign market is declared by the firm as the most important market for its output and zero otherwise.

It is worth stressing that, given the nature of our research problem, we have to rely on binary variables as dependent variables. This is due to the nature of the CIS questionnaire that includes neither the information on absolute export revenue, nor the information on the share of export revenue in firm's total turnover. ${ }^{4}$

In our study we selected a number of independent variables chosen from the survey, which should reflect the innovation efforts and important characteristics of analysed firms. The definitions of independent variables are presented in the Table 1 . We interpret variables 1 through 4 as characteristics of a firm's production factor endowment. In particular, prod_lines reflects capital endowment, $\mathrm{HC}$ - human capital endowment, and the dummy variables for firm size (medium, large) - labour endowment. Variables 5 through 7 are key characteristics of firm innovation performance, while variables 8-13 refer to the membership of firms in domestic or foreign capital groups. Finally, variables 14-16 characterize the sectors in which firms operate according to their technology intensity: controlling for sectoral effects is standard in innovation studies.

Since our dependent variables are binary variables to estimate the postulated relationship between the probability of exporting and various forms of innovation we use the probit model. The main advantage of this approach is that the dependent variable does not have to be continuous.

\footnotetext{
${ }^{3}$ In the past the methodology used three indicators of technology intensity reflecting, (1) R\&D expenditures divided by value added; (2) R\&D expenditures divided by production; and (3) R\&D expenditures plus technology embodied in intermediate and investment goods divided by production. The updated 2001 Scoreboard used ISIC Rev. 3 R\&D expenditure and output data to develop an updated technology classification based on an evaluation of R\&D intensities for 13 OECD countries for the period 1991-1997. The new edition extends the analysis to cover the period 1991-99, although for only 12 OECD countries.

${ }^{4}$ In their study of innovation complementarities, Lewandowska, Szymura-Tyc and Gołębiowski (2016) use the percentage of export revenues from new products in firm's total export revenues as the dependent variable. While this information is available in the CIS database, we cannot, unfortunately, use it to validate our hypothesis, which refers to firm's export orientation (as opposed to the focus on the domestic market).
} 
Table 1. List of independent variables used in the empirical analysis

\begin{tabular}{|c|c|c|}
\hline No. & Variable & Explanation of the variable \\
\hline 1. & prod_lines & Number of automatic product lines and controlled by the computers \\
\hline 2. & medium & Dummy variable indicating employment between 50 and 249 persons \\
\hline 3. & large & Dummy variable indicating employment exceeding 250 persons \\
\hline 4. & $H C$ & Human Capital: the percentage of employees with tertiary education \\
\hline 5. & product_innov & $\begin{array}{l}\text { Dummy variable indicating the market introduction of a new or signifi- } \\
\text { cantly improved good or service with respect to its capabilities, user } \\
\text { friendliness, components or sub-systems. }\end{array}$ \\
\hline 6. & process_innov & $\begin{array}{l}\text { Dummy variable indicating the implementation of a new or significantly } \\
\text { improved production process, distribution method, or supporting activity. }\end{array}$ \\
\hline 7. & intell_prop & $\begin{array}{l}\text { Dummy variable indicating applications for patents, inventions, trade- } \\
\text { marks, made in the Polish Patent Office }\end{array}$ \\
\hline 8. & group_pl & Dummy variable for the membership in the Polish capital group \\
\hline 9. & group fdi & Dummy variable for the membership in the foreign capital group \\
\hline 10. & group_de & Dummy variable for the membership in the German capital group \\
\hline 11. & group_fr & Dummy variable for the membership in the French capital group \\
\hline 12. & group_us & Dummy variable for the membership in the American capital group \\
\hline 13. & group_other & Dummy variable for the membership in the other foreign capital group \\
\hline 14. & ht & $\begin{array}{l}\text { Dummy variable for the high technology industry. The technology intensi- } \\
\text { ty of the manufacturing industries depends on R\&D intensities. See: the } \\
\text { Eurostat classification of R\&D intensities in the Annex. }\end{array}$ \\
\hline 15. & mht & $\begin{array}{l}\text { Dummy variable for the medium-high technology industry. See: the Euro- } \\
\text { stat classification of R\&D intensities in the Annex. }\end{array}$ \\
\hline 16. & $\mathrm{~m} / \mathrm{t}$ & $\begin{array}{l}\text { Dummy variable for the medium-low technology industry. See: the Euro- } \\
\text { stat classification of R\&D intensities in the Annex. }\end{array}$ \\
\hline
\end{tabular}

Comment: The variable prod_lines was used only in the Polish version of the questionnaire, as applied by the Polish Central Statistical Office (CSO).

Source: own study.

Our dependent variable indicating the export status of firm $i$ is denoted by $Y_{i}^{*}$. Instead of observing the volume of exports, we observe only a binary variable $Y_{i}$ indicating the sign of $Y_{i}^{*}$, i.e. whether the firm sells its output in the domestic market (local, regional or national) or it exports. Moreover, we assume that the variable $Y_{i}^{*}$ follows $Y_{i}^{*}=\mathbf{X}_{\mathbf{i}} \boldsymbol{\Theta}+\varepsilon_{i}$, where the error term $\varepsilon_{i}$ is independent of $\mathbf{X}_{\mathbf{i}}$ which is a vector containing explanatory variables that affect exports with the first term equal to unity for all $i, \boldsymbol{\Theta}$ is the vector of parameters on these variables that needs to be estimated and $\varepsilon_{i}$ is assumed to be normally distributed with a zero mean.

Our dependent variable follows a binary distribution and takes the value 1 when the firm exports and 0 otherwise:

$$
Y_{i}=\left\{\begin{array}{l}
1 \text { if } Y_{i}^{*}>0 \\
0 \text { if } Y_{i}^{*}=0
\end{array}\right.
$$

We can obtain the distribution of $Y_{i}$ given $\mathbf{X}_{\mathbf{i}}$. Hence, the probability that a firm exports can be written as: 


$$
P\left(Y_{i}=1 \mid \mathbf{X}_{\mathbf{i}}\right)=\Phi\left(\mathbf{X}_{\mathbf{i}} \boldsymbol{\Theta}\right)
$$

where:

$\Phi()$ - denotes the standard normal cumulative distribution function (cdf).

To be able to successfully employ the probit model, it is important to know how to interpret the vector of estimated parameters on the explanatory variables $\theta$. Consider a specific explanatory variable $x_{i j}$, which is an element of vector $\mathbf{X}_{\mathbf{i}}$. The partial effect of $x_{i j}$ on the probability of exporting can be written as:

$$
\frac{\partial P\left(Y_{i}=1 \mid \mathbf{X}_{\mathbf{i}}\right)}{\partial x_{i j}}=\frac{\partial p\left(\mathbf{X}_{\mathbf{i}}\right)}{\partial x_{i j}}
$$

When multiplied by $\Delta x_{i j}$ equation (3) gives the approximate change in $P\left(Y_{i}=1 \mid \mathbf{X}_{\mathbf{i}}\right)$ when $x_{i j}$ increases by $\Delta x_{i j}$, holding all other variables constant.

\section{RESULTS AND DISCUSSION}

In this section we present and discuss two sets of estimation results using two different definitions of dependent variables. First, in column (1) and (2) we discuss the results for firms that do export at least some of their output, and then in columns (3) and (4) for those for which export markets constitute the main market. The estimation covers period 2008-2010 and is obtained using the robust standard errors. The results of estimations are reported in the Table 2.

In column (1) of Table 2 we report the benchmark results on the relationship between innovation activities and export performance obtained for firms that do export at least some output. These results reveal that the estimated parameter on both measures of innovations, i.e. on product and process innovations, display expected positive signs, similar magnitudes and are statistically significant at $1 \%$ level. This means that the higher level of both product and process innovations are positively related to the higher probability of exporting.

We also investigated whether the probability of exports depends on the in-house creation of firm specific intangible assets by Polish firms. The control (intell_prop) variable used here is the measured by the number of firm applications for patents, inventions, trademarks, made in the Polish Patent Office. The estimated parameter for this variable is positive, but statistically not significant.

The other control variables are statistically significant at $1 \%$ level and reveal the expected signs. In particular, both variables describing firm size (medium and large) display large values and positive signs. The estimated parameter for large firms is bigger in comparison to medium firms, indicating the importance of economies of scale for exporting. The estimated parameter on the stock human capital $(\mathrm{HC})$ variable, describing percentage of employees with tertiary education, also displays a positive signs and is statistically significant at $1 \%$ level. Thus, a larger percentage of educated employees can be positively associated with probability of exporting. The number of product lines (prod-lines), proxying for the stock of capital and the differentiation of production profile, also reveals a positive sign, and is statistically significant at $1 \%$ level. Thus, the larger number 
of products offered, reflecting probably the larger stock of capital, can positively affect the probability of exporting.

Table 2. The list of estimated models

\begin{tabular}{|c|c|c|c|c|}
\hline Dependent variable: & $\begin{array}{l}\text { exporter } \\
\text { (1) }\end{array}$ & $\begin{array}{l}\text { exporter } \\
\text { (2) }\end{array}$ & $\begin{array}{c}\text { exporter_plus } \\
\text { (3) }\end{array}$ & $\begin{array}{c}\text { exporter_plus } \\
\text { (4) }\end{array}$ \\
\hline \multicolumn{5}{|l|}{ Independent variables: } \\
\hline prod_lines & $0.013^{* * *}(0.004)$ & & & $0.000(0.002)$ \\
\hline $\mathrm{HC}$ & $0.006 * * *(0.001)$ & & & $-0.006 * * *(0.001)$ \\
\hline medium & $0.605 * * *(0.031)$ & & & $0.344^{* * *}(0.034)$ \\
\hline large & $0.968 * * *(0.061)$ & & & $0.656^{* * *}(0.052)$ \\
\hline product_innov & $0.223^{* * *}(0.049)$ & & & $-0.197 * * *(0.047)$ \\
\hline process_innov & $0.245 * * *(0.047)$ & & & $0.025(0.043)$ \\
\hline intell_prop & $-0.001(0.006)$ & & & $-0.012 * *(0.005)$ \\
\hline group_pl & $-0.216 * * *(0.051)$ & & & $-0.331^{* * *}(0.056)$ \\
\hline group_fdi & $1.030 * * *(0.109)$ & & & \\
\hline group_de & & $1.104 * * *(0.148)$ & & $0.903^{* * *}(0.096)$ \\
\hline group_fr & & $1.596 * * *(0.342)$ & & $0.816^{* * *}(0.146)$ \\
\hline group_us & & $0.819 * * *(0.233)$ & & $0.904^{* * *}(0.162)$ \\
\hline group_other & & $0.937 * * *(0.124)$ & & $0.798^{* * *}(0.086)$ \\
\hline group_fdi x product_innov & $-0.148(0.156)$ & $-0.142(0.157)$ & $0.209 * *(0.091)$ & $0.211 * *(0.091)$ \\
\hline group_fdi $x$ HC & $-0.012 * * *(0.003)$ & $-0.011 * * *(0.003)$ & $-0.005^{*}(0.003)$ & $-0.005 *(0.003)$ \\
\hline group_fdi $x$ intell_prop & $0.046(0.052)$ & $0.049(0.055)$ & $-0.042(0.026)$ & $-0.042(0.026)$ \\
\hline $\mathrm{mlt}$ & $0.257^{* * *}(0.032)$ & $0.257^{* * *}(0.032)$ & $0.133 * * *(0.033)$ & $0.134^{* * *}(0.033)$ \\
\hline mht & $0.445 * * *(0.041)$ & $0.446 * * *(0.041)$ & $0.360 * * *(0.038)$ & $0.359 * * *(0.038)$ \\
\hline $\mathrm{Ht}$ & $0.060(0.082)$ & $0.066(0.082)$ & $0.203 * *(0.085)$ & $0.204^{* *}(0.084)$ \\
\hline constant & $-0.344 * * *(0.029)$ & $-0.344 * * *(0.029)$ & $-0.995 * * *(0.033)$ & $-0.995 * * *(0.033)$ \\
\hline Observations & 9,846 & 9,846 & 9,846 & 9,846 \\
\hline Pseudo $\mathrm{R}^{2}$ & 0.136 & 0.137 & 0.0825 & 0.0826 \\
\hline Log-likelihood & -5358 & -5354 & -5192 & -5191 \\
\hline
\end{tabular}

Robust standard errors in parentheses, *** $p<0.01,{ }^{* *} \mathrm{p}<0.05,{ }^{*} \mathrm{p}<0.1$

Source: own calculations in STATA.

Furthermore, the probability of exporting in Poland depends on the sector of economic activity. Our estimations results reveal that the largest probability of exporting exists in the medium-high technology sectors, such as of electrical equipment, motor vehicles, trailers or other transport equipment. The estimated parameter for mediumhigh-tech variable is positive and statistically significant at $1 \%$ level. The parameter for medium-low-tech is also positive and statistically significant at $1 \%$ level. Thus, Polish firms active in the sectors such as manufacturing of coke, basic metals or rubber and plastics have higher chances to be exporters. On the other hand, the firms active in low-tech sectors - such as production of food products, beverages and tobacco, textiles or wearing apparel and in high-tech sectors (e.g. production of pharmaceutical products, computers or electronic products) are also less export oriented. This pattern of export propensities in Poland reflects neoclassical pattern of trade analysed in other studies (Michałek \& Śledziewska, 2003). Poland, in comparison to other major partners from the 
EU-15, has revealed comparative advantage in more labour intensive sectors and capital intensive sectors.

Finally, the propensity to exports depends on the ownership structure. The variable group-p/ displays a negative sign and is statistically significant at $1 \%$ level. This result indicates the Polish-owned firms organized in capital groups are less export oriented compared to non-organized firms. On the other hand, the variable describing membership in foreign capital group group fdi displays a positive sign and is statistically significant at $1 \%$ level. Therefore, one can argue, the membership in the foreign capital group increases the probability of exporting. The similar results have been demonstrated in other empirical studies for other EU countries.

In column (2) of Table 2 we extend the study of the ownership structure and split the group_fdi variable into its major components. The variable group_pl still displays a negative sign and is statistically significant at $1 \%$ level. This result indicates the Polish-owned firms are less export oriented. On the other hand, all variables describing foreign ownership display positive signs and are statistically significant mostly at $1 \%$ level. The highest values of estimated parameters are reported in the case of French (group fr) and German (group_de) owned firms. Both of them are significant at $1 \%$ level. The lower values of parameters are displayed in the case of the US owned firms and firms from other countries.

In column (3) we report the results obtained for firms heavily depending on exports, for which the foreign market is the principal one. These results reveal some degree of similarity compared to the results reported in column (1). Main similarities include the importance for exporting and statistical significance of the size of the firm (medium and large), the ownership group variables and to some extent also the sectors of economic activity. The same sectors include medium low and medium high sectors which are more export oriented compared to the low tech sector.

The main difference with respect to the previous results is in the high technology sector which is more export oriented in the case of firms heavily depending on exports. On the other hand, the variables related to product innovations (product_innov), human capital $(H C)$ and intangible assets (intell_prop) are statistically significant but display counterintuitive, negative signs. We try to explore these counterintuitive results in column (4) in which we add three interaction variables: group fdi $x$ product_innov, HCx group_fdi and intell_Prop x group_fdi.

The first interaction term displays a positive sign and is statistically significant at $1 \%$ level. This means that firms that belong to a foreign group and introduce more new or significantly improved products have higher propensity to export. The second interaction term also displays a positive sign and is statistically significant at $1 \%$ level. This means that firms that belong to a foreign group and employ more educated employees have higher propensity to export. Finally, the third interaction term displays a negative sign and is statistically significant at $1 \%$ level. This means that firms that belong to a foreign group and make less applications for patents, inventions, trademarks in the Polish Patent Office, have higher propensity to export. This result might be due to the fact that a large fraction of Polish exports is accounted for by subsidiaries of multinational firms that do not register their patents and trademarks in Poland, but rather use the intellectual property created and protected by their parent firms. It can be also the case that large 
exporters may benefit from large scale of production that reduces average costs of production and are less interested in introducing innovations.

\section{CONCLUSIONS}

In this paper we studied the relationship between various types of innovations and export performance of Polish firms. Our analytical framework referred to the most recent strand in the new trade theory literature based on the Melitz (2003) model that stresses the importance of firm productivity in entering the export markets. The empirical implementation of the theoretical framework was based on the probit model and the unique Polish firm level data set covering the period 2008-2010.

In our approach we treated innovations as a key element that can increase the level of productivity and focused our analysis on both product and process innovations as well as intellectual property creation. We also tried to control for human capital and physical capital proxied by the percentage of employees with tertiary education and the number of production lines, respectively. In addition, we studied the role of foreign capital participation in determining firm export performance. In particular, we controlled for the country of origin of major investors in Poland.

Our estimation results indicate that the probability of exporting was positively related to product and process innovations, firm size, the share of university graduates in productive employment and foreign capital participation in the case of firms that export at least some fraction of their output. These results suggest the need for development of an innovation supporting mechanism that would stimulate both product and process innovations in Poland.

In the case of firms heavily dependent on exports the roles of innovations and intellectual property creation were obvious. The results depended also on the level of technology used in the analysed sector. In particular, the firms that operated in the medium high technology and medium low technology sectors were more export oriented in the case of all firms that export. Moreover, firms that were heavily dependent on exports revealed a higher propensity to export in the high technology sector but were less interested in introducing innovations. In future studies it would be desirable to investigate the robustness of these results using other estimation methods. In particular, the use of the logit model would be highly recommended.

\section{REFERENCES}

Atkeson, A., \& Burstein, A. (2007). Innovation, firm dynamics, and international trade. NBER Working Paper, No. 13326.

Aw, B.Y., Roberts, M.J., \& Xu, D.Y. (2009). R\&D investment, exporting, and productivity dynamics. NBER Working Paper, No. 14670.

Baily, M.N., \& Gersbach, H. (1995). Efficiency in manufacturing and the need for global competition. Brookings Papers on Economic Activity: Microeconomics, 307-358.

Basile, R. (2001). Export behavior of Italian manufacturing firms over the nineties: the role of innovation. Research Policy, 30, 1185-1201. 
Becker, S.O., \& Egger, P.H. (2013). Endogenous product versus process innovation and a firm's propensity to export. Empirical Economics, 44, 329-354.

Bernard, A., \& Jensen, J.B. (1999). Exceptional export performance: cause, effect, or both? Journal of International Economics, 47, 1-25.

Braunerhjelm, P. (1996). The relation between firm specific intangibles and exports. Economic Letters, 53, 213-219.

Caldera, A. (2010). Innovation and exporting: evidence from Spanish manufacturing firms. Review of World Economy, 146, 657-689.

Cassiman, B., \& Martínez-Ros, E. (2007). Innovation and exports: evidence from Spanish manufacturing. Unpublished manuscript, IESE Business School.

Cassiman, B., Golovko, E., \& Martínez-Ros, E. (2010). Innovation, exports and productivity. International Journal of Industrial Organization, 28, 372-376.

Cieślik, A., Michałek, J.J., \& Michałek, A. (2012). Determinanty działalności eksportowej polskich przedsiębiorstw. Gospodarka narodowa, LXXX/XXI (7-8), 67-84.

Cieślik, A., Michałek, J.J., \& Michałek, A. (2013). Export activity in Visegrad-4 countries: Firm level investigation. Ekonomia, 30, 5-24.

Cieślik, A., Michałek, J.J., \& Michałek, A. (2014). The influence of firm characteristics and export performance in Central and Eastern Europe: Comparisons of Visegrad Baltic and Caucasus states. Entrepreneurial Business and Economics Review, 2(1), 4-18.

Cieślik, A., Michałek, J.J., Michałek, A., \& Mycielski, J. (2015). Determinants of export performance: Comparison of Central European and Baltic firms. Czech Journal of Economics and Finance (Finance a uver), 65(3), 211-229.

Constantini, J.A., \& Melitz, M.J. (2008). The dynamics of firm-level adjustment to trade liberalization. In E. Helpman, D. Marin \& T. Verdier (Eds.), The organization of firms in a global economy. Cambridge, MA: Harvard University Press.

Damijan, J.P., Kostevc, C., \& Polanec, S. (2010). From innovation to exporting or vice versa? World Economy, 33(3), 374-398.

Damijan, J.P., \& Kostevc, C. (2006). Learning-by-exporting: Continuous productivity improvements or capacity utilization effects? Evidence from Slovenian firms. Review of World Economics, 142(3), 599-614.

De Loecker, J. (2007). Do exports generate higher productivity? Evidence from Slovenia. Journal of International Economics, 73(1), 69-98.

Dollar, D. (1986). Technological innovation, capital mobility, and the product cycle in North-South trade. American Economic Review, 76(1), 177-190.

Ebling, G., \& Janz, N. (1999). Export and innovation activities in the German service sector. Empirical evidence at the firm level. ZEW discussion paper, 99-53, Mannheim: Zentrum für Europäische Wirtschaftsforschung.

Entorf, H., Krader, W., \& Pohlmeier, W. (1988). Entscheidungen über Innovation, Beschäftigung und Außenhandel: Empirische Ergebnisse eines simultanen Probitansatzes. In H. Kräger (Ed.), Empirische Wirtschaftsforschung (pp. 27-49). Frankfurt: Campus Verlag. 
Eurostat (2016). Eurostat indicators on High-tech industry and Knowledge - intensive services Annex 3 - High-tech aggregation by NACE Rev.2. Retrieved on August 10, 2016 from http://ec.europa.eu/eurostat/cache/metadata/Annexes/htec_esms_an3 .pdf

Foellmi, R., \& Zweimüller, J. (2006). Mass consumption, exclusion, and unemployment. University of Zurich IEW working paper 296.

Grossman, G.M., \& Helpman, E. (1989). Product development and international trade. Journal of Political Economy, 97, 1261-1283.

Grossman, G.M., \& Helpman, E. (1990). Comparative advantage and long-run growth. American Economic Review, 80, 796-815.

Grossman, G.M., \& Helpman, E. (1991). Innovation and growth in the global economy. Cambridge, MA: MIT Press.

Grossman, G.M., Helpman, E., \& Szeidl, A. (2006). Optimal integration strategies for the multinational firm. Journal of International Economics, 70, 216-238.

Hagemejer, J., \& Kolasa, M. (2011). Internationalisation and economic performance of enterprises: Evidence from Polish firm-level Data. World Economy, 34(1), 74-100.

Hirsch, S., \& Bijaoui, I. (1985). R\&D Intensity and export performance: a micro view. Weltwirtschaftliches Archiv, 121, 138-151

Hopenhayn, H.A. (1992). Entry, exit, and firm dynamics in long run equilibrium. Econometrica, 60, 1127-1150.

Jensen, R., \& Thursby, M. (1987). A decision theoretic model of innovation, technology transfer, and trade. Review of Economic Studies, 54, 631-647.

Jovanovic, B. (1982). Selection and the evolution of industry. Econometrica, 50, 649-670.

Kumar, N., \& Siddharthan, N.S. (1994). Technology, firm size and export behavior in developing countries: the case of Indian enterprise. Journal of Development Studies, 32, 288-309.

Lachenmaier, S., \& Wößmann, L.W. (2006). Does innovation cause exports? Evidence from exogenous innovation impulses and obstacles using German micro data. Oxford Economic Papers, 58, 317-350.

Lewandowska, M.S., Szymura-Tyc, M., \& Gołębiowski, T. (2016). Innovation complementarity, cooperation partners, and new product export: Evidence from Poland. Journal of Business Research, 69(9), 3673-3681.

Martin, S. (1993). Endogenous firm efficiency in a Cournot principal-agent model. Journal of Economic Theory, 59, 445-450.

Melitz, M.J. (2003). The impact of trade on intra-industry reallocations and aggregate industry productivity. Econometrica, 71, 1695-1725.

Michałek, J.J., \& Śledziewska, K. (2003). Analiza handlu międzygałęziowego pomiędzy Polską a Unią Europejską. In J.J. Michałek, W. Siwiński \& M. Socha (Eds.), Od liberalizacji do integracji Polski z Uniq Europejskq. Mechanizmy i skutki gospodarcze (pp. 43-61). Warszawa: Wydawnictwo Naukowe PWN.

Roper, S., \& Love, J.H. (2002). Innovation and export performance: evidence from the UK and German manufacturing plants. Research Policy, 31, 1087-1102. 
Schlegelmilch, B.B., \& Crook, J.N. (1988). Firm-level determinants of export intensity. Managerial Decision Economics, 9, 291-300.

Segerstrom, P.S., Anant, T.C.A., \& Dinopoulos, E. (1990). A Schumpeterian model of the product life cycle. American Economic Review, 80, 1077-1091.

Spencer, B.J., \& Brander, J.A. (1983). International R\&D rivalry and industrial strategy. Review of Economic Studies, 50(4), 707-722.

Tybout, J.R. (2003). Plant- and Firm-Level Evidence on "New Trade Theories". In E.K. Choi \& J. Harrigan (Eds.), Handbook of International Trade (Chapter 13). Oxford: Basil Blackwell.

Van Beveren, I., \& Vandenbussche, H. (2010). Product and process innovation and firms' decision to export. Journal of Economic Policy Reform, 13(1), 3-24.

Wagner, J. (1996). Export performance, human capital, and product innovation in Germany: a micro view. Jahrbuch für Wirtschaftswissenschaften, 47, 40-45.

Wagner, J. (2007). Exports and Productivity: A Survey of the Evidence from Firm-level Data. The World Economy, 30(1), 60-82.

Wagner, J. (2012). A Comparison of Alternative Indicators for the Risk of Nonresponse Bias. Public Opinion Quarterly, 76(3), 555-575. doi: 10.1093/poq/nfs032

Wakelin, K. (1997). Trade and Innovation. Theory and Evidence. Cheltenham: Edward Elgar.

Wakelin, K. (1998). Innovation and export behaviour at the firm level. Research Policy, 26(7-8), 829-841. 


\section{Appendix}

Table A1. Classification of manufacturing industries into categories based on R\&D intensities

\begin{tabular}{|c|c|}
\hline High-technology industries & $\begin{array}{l}\text { NACE-Rev-2 } \\
\text { classification }\end{array}$ \\
\hline Manufacture of basic pharmaceutical products and pharmaceutical preparations & 21 \\
\hline Manufacture of computer, electronic and optical products & 26 \\
\hline \multicolumn{2}{|l|}{ Medium-high-technology industries } \\
\hline Manufacture of chemicals and chemical products & 20 \\
\hline Manufacture of electrical equipment & 27 \\
\hline Manufacture of machinery and equipment n.e.c. & 28 \\
\hline Manufacture of motor vehicles, trailers and semi-trailers & 29 \\
\hline Manufacture of other transport equipment & 30 \\
\hline \multicolumn{2}{|l|}{ Medium-low-technology industries } \\
\hline Manufacture of coke and refined petroleum products & 19 \\
\hline Manufacture of rubber and plastic products & 22 \\
\hline Manufacture of other non-metallic mineral products & 23 \\
\hline Manufacture of basic metals & 24 \\
\hline Manufacture of fabricated metal products, except machinery and equipment & 25 \\
\hline \multicolumn{2}{|l|}{ Low-technology industries } \\
\hline Manufacture of food products & 10 \\
\hline Manufacture of beverages & 11 \\
\hline Manufacture of tobacco products & 12 \\
\hline Manufacture of textiles & 13 \\
\hline Manufacture of wearing apparel & 14 \\
\hline Manufacture of leather and related products & 15 \\
\hline $\begin{array}{l}\text { Manufacture of wood and of products of wood and cork, except furniture; } \\
\text { manufacture of articles of straw and plaiting materials }\end{array}$ & 16 \\
\hline Manufacture of paper and paper products & 17 \\
\hline Printing and reproduction of recorded media & 18 \\
\hline Manufacture of furniture & 31 \\
\hline Other manufacturing & 32 \\
\hline
\end{tabular}

OECD Directorate for Science, Technology and Industry 7 July, 2011 Economic Analysis and Statistics Division, ISIC Rev. 3 Technology Intensity Definition, 7 July,2011

Source: Eurostat (2016). 


\section{Authors}

The contribution of co-authors is equal and expressed as $1 / 3(33.33 \%)$ each of the authors.

\section{Andrzej Cieślik}

Associate Professor in the area of International Economics in the Faculty of Economic Sciences of the University of Warsaw (Poland). PhD in Economics by the University of Warsaw.

Correspondence to: Prof. dr hab. Andrzej Cieślik; University of Warsaw, Faculty of Economic Sciences; ul. Długa44/50, 00-241 Warsaw, Poland; e-mail: cieslik@wne.uw.edu.pl

\section{Jan Jakub Michałek}

Associate Professor in the area of International Economics in the Faculty of Economic Sciences of the University of Warsaw (Poland). PhD in Economics by the University of Warsaw.

Correspondence to: Prof. dr hab. Jan Jakub Michałek; University of Warsaw, Faculty of Economic Sciences; ul. Długa44/50, 00-241 Warsaw, Poland; e-mail: michalek@wne.uw.edu.pl

\section{Krzysztof Szczygielski}

Assistant Professor in the area of International Economics in the Faculty of Economic Sciences of the University of Warsaw (Poland). PhD in Economics by the Warsaw School of Economics.

Correspondence to: Dr Krzysztof Szczygielski; University of Warsaw, Faculty of Economic Sciences; ul. Długa44/50, 00-241 Warsaw, Poland; e-mail: kszczygielski@wne.uw.edu.pl

\section{Acknowledgements and Financial Disclosure}

The first draft of the analysis was completed during the implementation of the project "Does Government Support for Innovation Matter? The Effectiveness of Public Support for Private Innovation", for which the data was provided by the Central Statistical Office (Szczecin branch). The contribution of Andrzej Cieślik and Jan Jakub Michałek was financed from the National Science Centre of Poland (NCN) project no. 2015/17/B/HS4/01 077 entitled "Innovation activity and export competitiveness in the new EU member countries".

The authors would like to thank the anonymous referees for their useful comments, which allowed to increase the value added of this article.

\section{Copyright and License}

This article is published under the terms of the Creative Commons Attribution - NonCommercial - NoDerivs (CC BY-NC-ND 3.0) License

http://creativecommons.org/licenses/by-nc-nd/3.0/ 